\title{
Unusual sauropod tracks in the Jurassic-Cretaceous interval of the Cameros Basin (Burgos, Spain)
}

\author{
F. Torcida Fernández-Baldor ${ }^{1 *}$, I. Díaz-Martínez², R. Contreras ${ }^{1}$, P. Huerta ${ }^{1,2}$, \\ D. Montero ${ }^{1}, \mathrm{~V}$. Urién ${ }^{1}$ \\ ${ }^{I}$ Museo de Dinosaurios de Salas de los Infantes y Colectivo Arqueológico-Paleontológico de Salas, Pza. Jesús Aparicio, \\ 09600 Salas de los Infantes (Burgos), Spain. \\ ${ }^{2}$ CONICET - Instituto de Investigación en Paleobiología y Geología, Universidad Nacional de Río Negro, c/ General Roca \\ 1242, 8332 Fisque Menuco-General Roca (Río Negro), Argentina. \\ ${ }^{3}$ Departemaneto de Geología, Escuela Politécnica Superior de Ávila, Universidad de Salamanca, 05003 Ávila, Spain. \\ e-mail addresses: fideltorcida@hotmail.com (F.T.F.-B., corresponding author); inaportu@hotmail.com (I.D.M.); contr_ruben@hotmail.com \\ (R.C.); phuerta@usal.es (P.H.); monteropodo@hotmail.com (D.M.); victorum23@gmail.com (V.U.)
}

Received: 15 January 2014 / Accepted: 18 December 2014 / Available online: 25 March 2015

\begin{abstract}
The Las Sereas site includes at least 14 ichnological outcrops along $5.6 \mathrm{~km}$, in the Lara area, southwest Burgos Province. 67 ichnites of dinosaurs are documented at Las Sereas 7, identified as theropod and sauropod trackways occurring in shallow carbonates of lacustrine environment. Sauropod trackways have intermediate-gauge and low heteropody, and show different anatomical features to other tracks found in the ichnological record, especially in the disposition and orientation of pes digits. They are similar to Polyonyx from the Middle Jurassic of Portugal. However, since they do not preserve reliable manus data they are classified as aff. Polyonyx. The three sauropod trackways are related to the same kind of trackmaker. They differ from each other only in size, and gregarious behavior has not been detected. Analysis of these trackways reveals changes in travel direction even when there are few tracks in each sequence. At the Las Sereas 7 tracksite, the pace length (PL), width of the angulation pattern (WAP) and the WAP/PL ratio and depth analysis via photogrammetry show a direction change in two sauropod trackways. This tracksite and that at La Pedraja are unique in the Tithonian-Berriasian interval of the Iberian Peninsula that occur in a lacustrine environment, and could be indicate of the relationship between the diversity of Iberian, Tithonian-Berriasian sauropod tracks and sedimentary environments.
\end{abstract}

Keywords: Dinosaurs, Sauropod tracks, Tithonian, Berriasian, Cameros Basin, Iberia

\section{Resumen}

El yacimiento de Las Sereas se compone de al menos 14 afloramientos icníticos que se localizan a lo largo de 5,6 Km de longitud en la comarca de Lara, en el sureste de la provincia de Burgos. En el afloramiento de Las Sereas 7 se han documentado 67 icnitas de dinosaurios, identificadas como terópodas y saurópodas, producidas en un ambiente lacustre carbonatado somero. Las rastros saurópodos son de anchura intermedia y heteropodia baja mostrando caracteres anatómicos diferentes a los encontrados en el registro icnológico conocido, en especial en lo referente a la disposición y orientación de los dedos del pie. La mayor semejanza de estas icnitas saurópodas se establece con Polyonyx del Jurásico Medio de Portugal, pero al carecer de datos fiables sobre la anatomía de las manos en Las Sereas, clasificamos estas icnitas de Burgos como aff. Polyonyx. Los tres rastros saurópodos de Burgos se atribuyen a un mismo icnopoyeta, diferenciándose entre sí sólo por el tamaño, y sin que se haya detectado un comportamiento gregario. En el estudio de estos rastros pueden recogerse datos que informen sobre trayectos con cambio de dirección, incluso cuando lo que se conserva es una serie relativamente corta de pasos. En Las Sereas 7 la combinación de los valores de varios parámetros - longitud de paso (PL), pauta de anchura de angulación (WAP) y relación WAP/PL - y el estudio de la profundidad de las icnitas por fotogrametría permiten interpretar un cambio de dirección en dos de los rastros saurópodos. Este yacimiento y el de La Pedraja son los únicos conocidos en el registro del intervalo Titoniense-Berriasiense de la Península Ibérica que se formaron en un medio lagunar. En este sentido, podría haber una relación entre la diversidad de icnitas saurópodas ibéricas del intervalo Titoniense-Berriasiense y la presencia de éstas en distintos medios sedimentarios.

Palabras clave: Dinosaurios, rastros saurópodos, Titoniense, Berriasiense, Cuenca de Cameros, Iberia 


\section{Introduction}

In the Iberian Peninsula, the dinosaur ichnological record of Tithonian-Berriasian (Jurassic-Cretaceous transition) interval is abundant. Tracksites have been found in the Tithonian of Portugal (e.g., Santos, 2003; Mateus and Milàn, 2008, 2010), and in the Tithonian-Berriasian interval (e. g., Torcida Fernández-Baldor et al., 2001, 2012; Castanera et al., 2010a; 2011) and the Berriasian (e. g., Casanovas et al. 1992; 1995a; 1995b; 1995c; Pascual-Arribas et al., 2008; Castanera et al., 2010 b; 2012) of the Iberian Range in Spain.

Some authors have suggested that there are differences between Jurassic and Cretaceous dinosaur ichnofaunas (e. g., Lockley et al., 2004; Hunt and Lucas, 2006; Moratalla, 2009). For example, Hunt and Lucas (2006) considered that ornithopod tracks are more abundant in Cretaceous outcrops. Lockley et al. (2004) observed that narrow-gauge sauropod trackways are predominant in Jurassic units and wide-gauge in the Cretaceous ones. Therefore, the study of TithonianBerriasian interval tracksites from Iberia is important for understanding dinosaur evolution.

La Pedraja is the only tracksite analyzed in detail in the Tithonian-Berriasian of the Cameros basin (Platt and Meyer, 1991; Torcida Fernández-Baldor et al., 2001). Torcida Fernández-Baldor et al. (2012) published a preliminary study of 13 tracksites, called Las Sereas in which La Pedraja tracksite is included, showing its potential importance for the Tithonian-Berriasian interval dinosaur ichnodiversity. Las Sereas 7 presents sauropod trackways with different morphological features from other ichnotaxa described in the literature, especially at the same time interval. The aims of this paper are to describe in detail the Las Sereas 7, one of the tracksites in the Tithonian-Berriasian of the Cameros basin (Rupelo Fm.) (Platt, 1986), to discuss the ichnotaxonomy of the quadruped and biped trackways, and to compare them with similar ichnofaunas from Tithonian-Berriasian interval in the Iberian Peninsula.

\section{Geographical and Geological Setting}

Las Sereas 7 tracksite is located in SW of Burgos Province, close to the road (BU-V-8207) connecting Quintanilla de las Viñas with the road N-234 (Fig. 1). The tracksite together with La Pedraja tracksite is part of the Las Sereas outcrop, extending 5.6 Km from Quintanilla de las Viñas to Mambrillas de Lara villages (Torcida Fernández-Baldor et al., 2006; 2012) and exposes a limestone unit known as Rupelo Fm. (Platt, 1986; Platt, 1989; Clemente, 2010). Las Sereas 7 occurs in the uppermost bed of the Rupelo Fm. which is overlied by the red mudstones.

The Rupelo Fm. is characterized by palustrine limestones with abundant intraclastic breccias, peloidal texture, pseudomicrokarst, root marks, and limnic fossils like charophytes, ostracods, and gastropods (Platt, 1989). The deposits are interpreted as a low gradient lake margin that exposed/inun- dated large areas with slight changes in water level. Similar examples have been described in the Cenozoic deposits of the Duero and Tajo basins (Alonso-Zarza, 2003; Alonso-Zarza et al., 1992; Huerta and Armenteros, 2005; Huerta et al., 2011).

The age of the Rupelo Fm. and equivalents stratigraphic units proposed by other authors is assigned to the TithonianBerriasian interval (Martín-Closas and Alonso Millán, 1998) on the basis of charophyte biostratigraphy. The formation contains dinosaur bone remains as well (Torcida FernándezBaldor, 1996; Torcida Fernández-Baldor et al., 2008).

\section{Material, methods, and nomenclature}

The Las Sereas 7 tracksite shows 67 tracks in six trackways, made by three bipeds and three quadrupeds, in a small outcrop $\left(72 \mathrm{~m}^{2}\right)$. This outcrop was excavated and cleaned in the summer of 2010 and initially revealed 45 dinosaur tracks. The tracksite was cross-linked and photographed to create an ichnological map. In 2011, the tracksite was restored and protected within an enhancement project. In 2013 a new part of the outcrop was excavated and 22 new dinosaur tracks were obtained, some of them being continuations of previously identified trackways.

The tracks are arranged in six trackways belonging to three quadrupeds and three bipeds, and there are several isolated tracks as well (Figs. 2, 3). The 67 dinosaur tracks recognized were labeled according to previous convention (e.g., Casanovas Cladellas et al., 1989; Pérez-Lorente, 2003) as follows: first, the tracksite identification (e.g., LS7); second, the trackway (e.g., B); third, separated by a comma, the footprint (e.g., 3 ); and fourth in quadruped footprints, pes or manus (e.g., p or $\mathrm{m}$ ). For instance, LS7B,3p is the pes impression of the third pes impression of trackway B of tracksite LS7 (Las Sereas 7).

The measurements and nomenclature used in this study are mainly based on the work of Haubold (1971), Casanovas Cladellas et al. (1989), Thulborn (1990), and Pérez-Lorente (2001). Several measurements were made (Tables 1, 2, 3): footprint length (FL), footprint width (FW), digit length (DLII, III, IV), digit angulation (III $\left.{ }^{\wedge} \mathrm{IV}, \mathrm{II}^{\wedge} \mathrm{III}, \mathrm{II}^{\wedge} \mathrm{IV}\right)$, footprint rotation (FR), pace length (PL), stride length (SL), inner and outer trackway width (iTW-eTW), pace angulation $(\mathrm{ANG})$, manus-pes distance (Dm-p), width of the angulation pattern (WAP), and glenoacetabular distance (Dga), sensu Leonardi (1987). The heteropody was calculated with the heteropody index (HI) using the formula of González Riga and Calvo (2009): $\mathrm{HI}=[(\mathrm{Lm} \times \mathrm{Wm}) /(\mathrm{Lp} \times \mathrm{Wp})]^{* 100 \text {, and }}$ with the manus-pes area ratio $(\mathrm{H})$ of Lockley et al. (1994a). In addition, to quantify the trackway gauge, the pes and manus trackway ratio (PTR and MTR) was calculated as TR $=(\mathrm{FW} / \mathrm{eTW}) 100$ (Romano et al., 2007) along with the WAP/ PL ratio (Marty et al., 2010). The hip height (h) and the locomotion speed (v) were estimated using Alexander's (1976) formulas: $\mathrm{h}=4 \mathrm{FL}$ (quadrupeds), $\mathrm{v}=0.25 \mathrm{~g}^{0.5} \mathrm{x} \mathrm{SL}^{1.67} \mathrm{x} \mathrm{h}^{-1.17}$ and Thulborn's (1990) formula: $\mathrm{h}=3.14 \times \mathrm{FL}^{1.14}$ (theropods). All parameters are given and compared in $\mathrm{cm}$, except FR and 
Fig.1.- Geographical and geological setting of Las Sereas 7 tracksite.

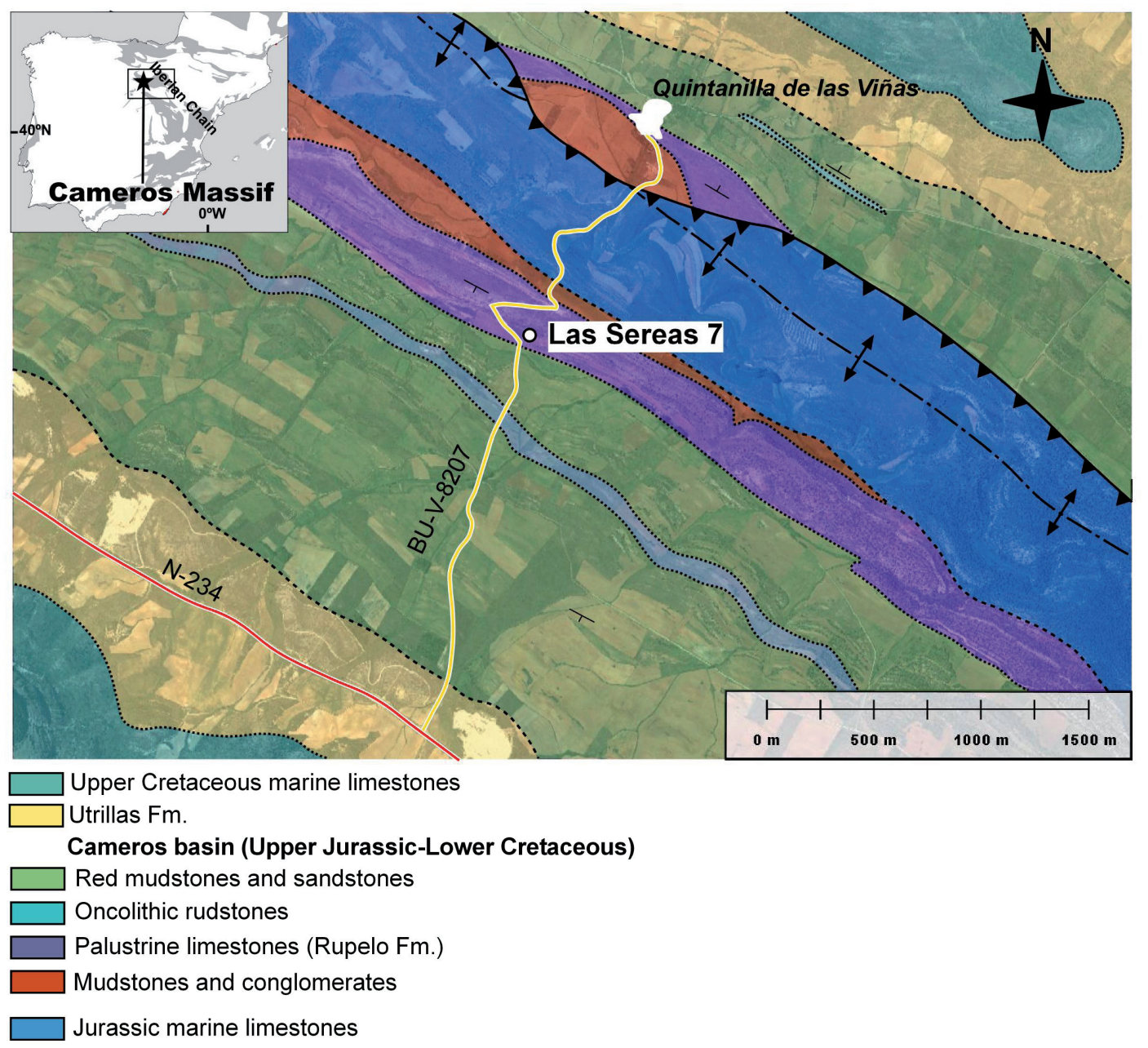

ANG (in degrees), $\mathrm{H}$ (adimensional), HI, PTR and MTR (in $\%$ ), and locomotion speed (in $\mathrm{km} / \mathrm{h}$ ).

The photogrammetric images (Falkingham, 2012) were obtained using Agisoft PhotoScan ${ }^{\mathrm{TM}}$ (version 0.8.5.1423) software (Grupo Aragosaurus, Universidad de Zaragoza License) both for quadruped and tridactyl tracks with the aim of studying the track morphology through depth maps and contour lines. This method provides for an accurate study of the print depths, which are not easily discernible using traditional methods (mainly because the tracks have large rims and the surface is irregular). Photogrammetric models were also imported into Meshlab ${ }^{\mathrm{TM}}$ (http://meshlab.sourceforge. net/) for scaling and Paraview ${ }^{\mathrm{TM}}$ (http://www.paraview.org/) to generate false-color maps and contour lines.

\section{Description of Las Sereas 7 dinosaur tracks}

\subsection{Biped dinosaur trackways}

\section{Trackway $L S 7 D$}

LS7D has seven large, tridactyl and mesaxonic footprints aligned east-west (Figs. 2, 3, 4). They are longer than wide (FL: $43 \mathrm{~cm}$, FW: $34 \mathrm{~cm}$; Table 1) and the digit impressions are forwardly directed. Well-preserved footprints, LS7D,1 and LS7D,4, are characterized by having longer than wide digit impressions with pointed distal ends and some pad impressions in each digit. The angle between digits II and III is smaller than between III and IV. The heel impression is asymmetric bilobed and is formed by the proximal pads of digit II and IV: IV biggest than II and backward situated what yields an indentation in the inner side of the footprint. The other footprints of LS7D are deformed, poorly-preserved, or have obliterated digit marks. The LS7D, 4 track is approximately $10 \mathrm{~cm}$ deep.

The trackway is very narrow, according to the ratio between iTW/FW (0.3) (sensu Pérez-Lorente, 2001). The trackmaker would have had thick limbs $(\mathrm{SL} / \mathrm{FL}=4.8)$ and would have walked $(\mathrm{SL} / \mathrm{H}=0.83)$ with a speed average of $3.5 \mathrm{~km} / \mathrm{h}$ (sensu Pérez-Lorente, 2001).

\section{Trackway LS7E}

LS7E consists of three large, tridactyl and mesaxonic footprints that are oriented east-west (Fig. 2). They have longer than wide digit impressions with acuminate distal ends and bilobed heel impressions. The footprints are longer than wide (43 cm of length and $33 \mathrm{~cm}$ of wide; see Table 1). They are fairly deformed and LS7E, 3 show very elongated digit impressions due to mud collapse structures. 


\begin{tabular}{cccccccccc} 
Trackway LS7D & FL & FW & DLII & DLIII & DLIV & III IV $^{\wedge}$ & II III $^{\wedge}$ & II IV $^{\wedge}$ & PL \\
\hline LS7D, 1 & 49 & 35 & 12 & 27 & 20 & $2^{\circ}$ & $22^{\circ}$ & $24^{\circ}$ & - \\
LS7D, 2 & 37 & 32 & 10 & 17 & 10 & $1^{\circ}$ & $35^{\circ}$ & $36^{\circ}$ & 112 \\
LS7D, 3 & 40 & - & - & - & - & - & - & - & 104 \\
LS7D, 4 & 46 & - & 18 & 23 & - & - & $44^{\circ}$ & - & 92 \\
LS7D, 5 & - & - & - & - & - & - & - & - & 105 \\
LS7D, 6 & $(35)$ & $(41)$ & - & - & - & - & - & - & 102 \\
LS7D, 7 & - & $(33)$ & - & - & - & - & - & - & 107 \\
\hline AVERAGE & 43 & 34 & 13 & 22 & 15 & $2^{\circ}$ & $34^{\circ}$ & 30 & 104 \\
\hline & & & & & & & & & \\
Trackway LS7D & iTW & eTW & FR & ANG & iTW/FW & DLIII /FL & SL/FL & h & v $(\mathrm{km} / \mathrm{h})$ \\
\hline LS7D, 1 & & & & & & 0.55 & & 265 & \\
LS7D, 2 & 10 & 50 & $4^{\circ}$ & $157^{\circ}$ & 0.3 & 0.46 & 5.7 & 193 & 4.6 \\
LS7D, 3 & 15 & 58 & - & $145^{\circ}$ & - & - & 4.7 & 211 & 3.3 \\
LS7D, 4 & 19 & 73 & $4^{\circ}$ & $133^{\circ}$ & - & 0.5 & 3.9 & 247 & 2.6 \\
LS7D, 5 & 19 & 76 & - & $138^{\circ}$ & - & - & - & - & - \\
LS7D, 6 & 21 & 84 & - & $129^{\circ}$ & 0.5 & - & $(5.4)$ & $(181)$ & $(4.1)$ \\
LS7D, 7 & - & - & - & - & - & - & - & - & - \\
\hline AVERAGE & 17 & $(68)$ & $4^{\circ}$ & $140^{\circ}$ & 0.3 & 0.5 & 4.8 & 229 & 3.5 \\
\hline
\end{tabular}

Table 1.- Measurements of biped trackways from Las Sereas 7 (Burgos, Spain). Footprint length (FL), footprint width (FW), digit length (DLII, III, IV), digit angulation (III^IV, II^III, II^IV), pace length (PL), stride length (SL), inner and outer trackway width (iTW-eTW), footprint rotation (FR), pace angulation (ANG), hip height (h) and speed value by the Alexander's (1976) formula (V).

\section{Trackway LS7F}

This probable trackway has three, non-consecutive, large, tridactyl and mesaxonic footprints. These footprints are longer than wide, with short digit impressions and a rounded distal end (Fig. 2; Table 1). The heel impressions are broad, with rounded contours. They are very shallow and their general contour line is not clear. The trackway is directed northwest.

\subsection{Quadruped dinosaur trackways}

Three of the sauropod trackways that have been identified show similar features; two of them are equal size, and the third is smaller and poorly preserved.

\section{Trackway $L S 7 A$}

The trackway LS7A comprises 20 tracks aligned northeast to southwest (Fig. 2; Table 2) and forming a smooth curve to the right in the forward direction. Pes prints are longer (from $54 \mathrm{~cm}$ to $66 \mathrm{~cm}$ ) than wide (from $39 \mathrm{~cm}$ to $50 \mathrm{~cm}$ ), with subrectangular shape and the posterior edge slightly protruding. They have four claw marks occupying the entire width of the anterior zone, with the external claw (claw IV) located laterally and the internal claw (claw I) medially. Claw mark I is more proximal than the others, is smaller than claw mark II and III, and is forward-directed; claw mark II is also forward-directed, while III and IV are laterally-oriented (Figs. 3, 4, 5). The manus prints are roughly symmetrical, wider (from $36 \mathrm{~cm}$ to $46 \mathrm{~cm}$ ) than long (from $21 \mathrm{~cm}$ to 37 $\mathrm{cm})$. Shape is variable, kidney- or crescent-like, determined by the partial obliteration by mud displaced by the hind limb impression. Another observed morphology, oval and wider than long, is considered to better record the real shape of the hand (LS7A, $7 \mathrm{~m}, 8 \mathrm{~m}$ and $10 \mathrm{~m}$ ). In the LS7A,8m and LS7A, 10m manus prints, three to four forwardly directed digit impressions have been preserved. The manus prints are farther from the midline than the pes prints. The glenoacetabular distance is about $180 \mathrm{~cm}$.

Track rotations show very variable values, between $7^{\circ}$ and $33^{\circ}$ for pes, and between $22^{\circ}$ and $30^{\circ}$ for manus prints. These values and the pace angulation values decrease in the middle of the trackway. The pace angulation is higher in the first part of the trackway, in the middle part decreases, and increases apparently at the end (varies between $85^{\circ}$ and $105^{\circ}$ ). According to Castanera et al. (2012) these changes are consistent with a turning trackway.

The speed values correspond to a slow walk (from 1.3 to $1.8 \mathrm{Km} / \mathrm{h}$ ), and there is no significant variation along the trackway. The heteropody value is 1:2.5 and the heteropody index $41 \%$, corresponding to low values in the two cases. Pes prints are deeper than manus prints, although in LS7A, 6 (Fig. 4, Table 2) both have about $20 \mathrm{~cm}$ deep.

This trackway is narrow-gauge at the beginning part and middle in the rest. The PTR value (Romano et al., 2007) of $43.9 \%$, corresponds to middle gauge trackway. The WAP/ PL value of 0.59 suggests a narrow gauge trackway according to Marty (2008). There are published trackways with changes in gauge along turns. For example, in the turning area the trackway gauge is narrow, and in the straight part is middle or wide (Castanera et al., 2012). For LS7A, the turning is continuously to the right, but in the final part of the trackway it is difficult to determine if turning is constant or is more or less pronounced. 

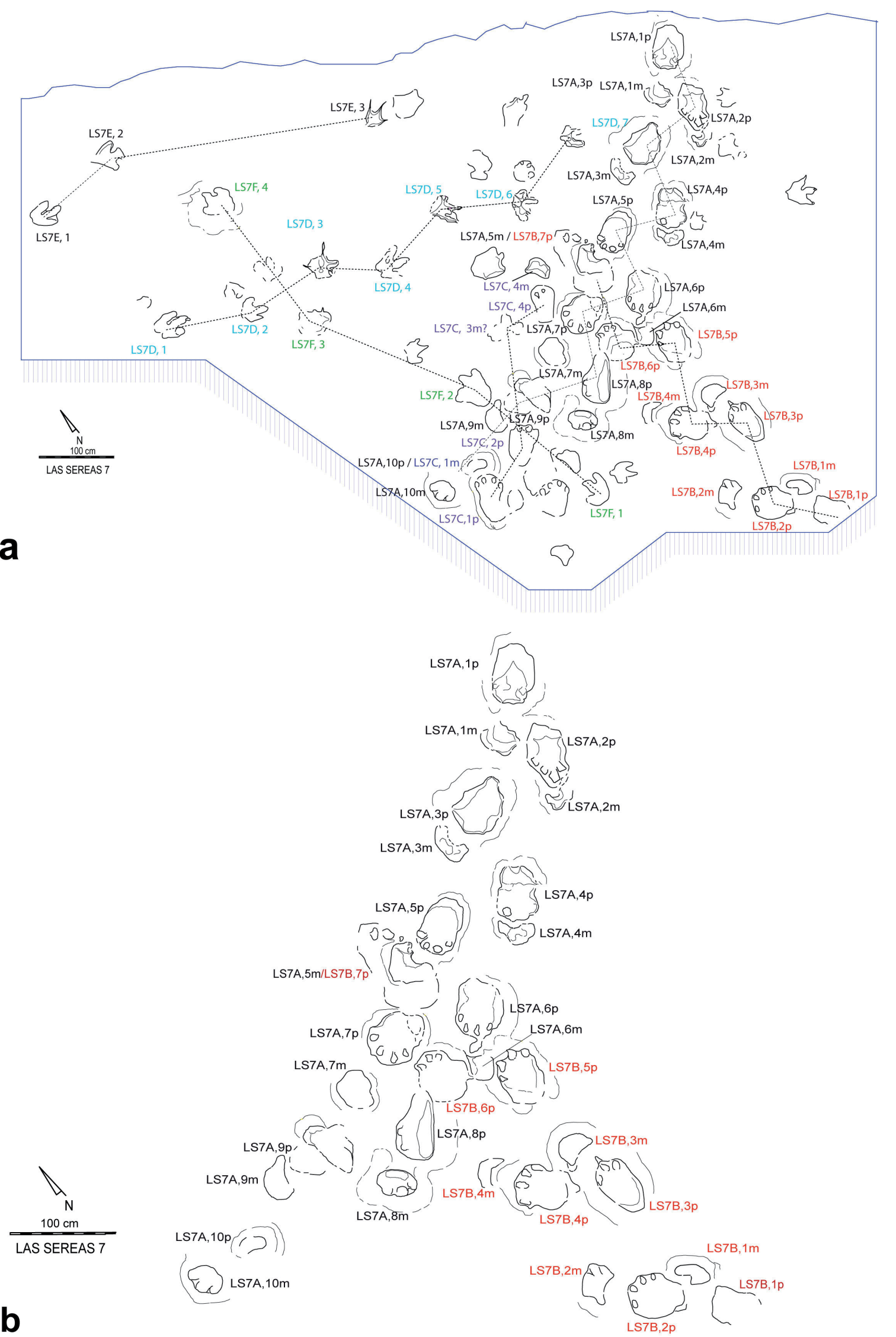

Fig.- 2. a) Schematic map of the Las Sereas 7 tracksite; the arrows indicate the direction of progression of each trackway, and the outer lines the limits of the excavactions. b) Detail of the trackways LS7A and LS7B. The fine lines inside and around the tracks indicates respectively the collapsed and displaced mud. 


\begin{tabular}{|c|c|c|c|c|c|c|c|c|}
\hline Trackway LS7A & FL & FW & PL & SL & iTW & eTW & FR & ANG \\
\hline LS7A, 1 p/m & $61 / 30$ & $41 / 36$ & & & & & & \\
\hline LS7A, 2 p/m & $66 /-$ & $39 /-$ & $86 / 86$ & $132 / 116$ & $7 / 45$ & $100 / 111$ & $33^{\circ} / 30^{\circ}$ & $105^{\circ} / 67^{\circ}$ \\
\hline LS7A, 3 p/m & $61 / 21$ & $46 / 39$ & $82 / 118$ & $141 / 138$ & $11 / 52$ & $102 / 111$ & $13^{\circ} / 25^{\circ}$ & $101^{\circ} / 75^{\circ}$ \\
\hline LS7A, 4 p/m & $54 / 21$ & $41 / 36$ & $93 / 113$ & $123 / 128$ & $18 /-$ & $107 / 114$ & $18^{\circ} / 22^{\circ}$ & $90^{\circ} / 75^{\circ}$ \\
\hline $\mathrm{LS} 7 \mathrm{~A}, 5 \mathrm{p} / \mathrm{m}$ & $57 / 36$ & $39 / 46$ & $80 / 114$ & $120 / 134$ & $18 /-$ & $104 / 109$ & $7^{\circ} / 23^{\circ}$ & $89^{\circ} / 71^{\circ}$ \\
\hline LS7A, 6 p/m & $61 /-$ & $46 /-$ & $91 / 123$ & $118 / 130$ & $18 /-$ & $111 / 121$ & $16^{\circ} /-$ & $85^{\circ} / 63^{\circ}$ \\
\hline LS7A, 7 p/m & $61 / 37$ & $50 / 41$ & $84 / 125$ & $130 / 140$ & $-/-$ & $113 / 115$ & $22^{\circ} / 33^{\circ}$ & $95^{\circ} / 77^{\circ}$ \\
\hline LS7A, 8 p/m & $66 / 31$ & $38 / 40$ & $87 / 100$ & $-/ 121$ & $-/-$ & $-/ 125$ & $-1-$ & $-/ 68^{\circ}$ \\
\hline $\mathrm{LS} 7 \mathrm{~A}, 9 \mathrm{p} / \mathrm{m}$ & $-/ 27$ & $-/ 42$ & - / 117 & $-1-$ & $-/ 92$ & $-1-$ & $-1-$ & $-1-$ \\
\hline LS7A, 11 p/m & $-/ 27$ & $-/ 35$ & $-1-$ & $-/ 115$ & & $-1-$ & $-1-$ & $-1-$ \\
\hline AVERAGE & $60 / 29$ & $43 / 40$ & $86 / 112$ & $127 / 128$ & $14 / 63$ & $106 / 115$ & $18^{\circ} / 27^{\circ}$ & $94^{\circ} / 71^{\circ}$ \\
\hline Trackway LS7A & $\mathbf{H}$ & HI & PTR & MTR & WAP & WAP / PL & h & $\mathbf{v}(\mathbf{k m} / \mathbf{h})$ \\
\hline LS7A, 1 p/m & $1: 2.3$ & 43 & - & - & & & 244 & - \\
\hline LS7A, 2 p/m & - & - & 46.4 & 18.9 & $53 / 80$ & 0.62 & 264 & 1.4 \\
\hline LS7A, 3 p/m & $1: 3.4$ & 29 & 46.5 & 32.8 & $61 / 93$ & 0.74 & 244 & 1.8 \\
\hline $\mathrm{LS} 7 \mathrm{~A}, 4 \mathrm{p} / \mathrm{m}$ & $1: 2.9$ & 34 & 42.5 & - & $61 / 89$ & 0.66 & 216 & 1.6 \\
\hline $\mathrm{LS} 7 \mathrm{~A}, 5 \mathrm{p} / \mathrm{m}$ & $(1: 1.3)^{*}$ & $(74)^{*}$ & 38.3 & - & $66 / 100$ & 0.66 & 228 & 1.5 \\
\hline $\mathrm{LS} 7 \mathrm{~A}, 6 \mathrm{p} / \mathrm{m}$ & - & - & 46 & - & $-1-$ & - & 244 & 1.3 \\
\hline LS7A, 7 p/m & $1: 2$ & 50 & - & - & $58 /-$ & 0.69 & 244 & 1.5 \\
\hline $\mathrm{LS} 7 \mathrm{~A}, 8 \mathrm{p} / \mathrm{m}$ & $1: 2$ & 49 & - & - & $-/ 88$ & - & 264 & - \\
\hline LS7A, 9 p/m & - & - & - & - & $-1-$ & - & - & - \\
\hline LS7A, 11 p/m & - & - & - & - & $-1-$ & - & - & - \\
\hline$A V E R A G E$ & $\begin{array}{c}1: 2.5 \\
\text { except } *\end{array}$ & $\begin{array}{c}41 \% \\
\text { except } *\end{array}$ & 43.9 & 25.8 & $60 / 90$ & 0.67 & 244 & 1.5 \\
\hline
\end{tabular}

Table 2.- Measurements of quadruped trackway LS7A from Las Sereas 7 (Burgos, Spain). Abbreviations as in table 1, and in addition: manus-pes distance $(\mathrm{Dm}-\mathrm{p})$, heteropody $(\mathrm{H})$ and heteropody index $(\mathrm{HI})$, pes trackway ratio (PTR), manus trackway ratio (MTR), width of the angulation pattern (WAP),. All parameters are given and compared in cm, except FR and ANG in degrees, heteropody, H (adimensional), HI, PTR and MTR in \%, and locomotion speed value in $\mathrm{km} / \mathrm{h}$.

\begin{tabular}{|c|c|c|c|c|c|c|c|c|}
\hline Trackway LS7B & FL & FW & PL & SL & iTW & eTW & FR & ANG \\
\hline $\mathrm{LS} 7 \mathrm{~B}, 1 \mathrm{p} / \mathrm{m}$ & - & - & - & - & - & - & - & - \\
\hline $\mathrm{LS} 7 \mathrm{~B}, 2 \mathrm{p} / \mathrm{m}$ & $78 / 35$ & $48 / 21$ & $83 / 102$ & $171 / 177$ & $3 / 46$ & $100 / 109$ & $34^{\circ} / 30^{\circ}$ & $123^{\circ} / 95^{\circ}$ \\
\hline $\mathrm{LS} 7 \mathrm{~B}, 3 \mathrm{p} / \mathrm{m}$ & $65 / 29$ & $37 / 38$ & $117 / 135$ & $156 / 154$ & $19 / 21$ & $104 / 113$ & $8^{\circ} / 5^{\circ}$ & $74^{\circ} / 85^{\circ}$ \\
\hline $\mathrm{LS} 7 \mathrm{~B}, 4 \mathrm{p} / \mathrm{m}$ & $54 / 25$ & $44 / 34$ & $77 / 90$ & $146 /-$ & $19 /-$ & $106 /-$ & $28^{\circ} /-$ & $100^{\circ} /-$ \\
\hline $\mathrm{LS} 7 \mathrm{~B}, 5 \mathrm{p} / \mathrm{m}$ & $60 / 21$ & 44 / 31 & $113 /-$ & $150 /-$ & $13 /-$ & $106 /-$ & $12^{\circ} /-$ & $102^{\circ} /-$ \\
\hline $\mathrm{LS} 7 \mathrm{~B}, 6 \mathrm{p} / \mathrm{m}$ & $58 /-$ & $-1-$ & $79 /-$ & $-1-$ & $-1-$ & $-1-$ & $-1-$ & $-1-$ \\
\hline $\mathrm{LS} 7 \mathrm{~B}, 7 \mathrm{p} / \mathrm{m}$ & $-1-$ & $-1-$ & $-1-$ & $-1-$ & $-1-$ & $-1-$ & $-1-$ & $-1-$ \\
\hline AVERAGE & $63 / 28$ & $43 / 31$ & $94 / 109$ & $156 / 166$ & $13.5 / 34$ & $104 / 111$ & $21^{\circ} / 18^{\circ}$ & $100^{\circ} / 90^{\circ}$ \\
\hline Trackway LS7B & $\mathbf{H}$ & HI & PTR & MTR & WAP & WAP / PL & h & $\mathbf{v}(\mathbf{k m} / \mathbf{h})$ \\
\hline $\mathrm{LS} 7 \mathrm{~B}, 1 \mathrm{p} / \mathrm{m}$ & - & - & & & & & - & - \\
\hline $\mathrm{LS} 7 \mathrm{~B}, 2 \mathrm{p} / \mathrm{m}$ & $1: 5.1 *$ & $20 *$ & 56.3 & 32.5 & $50 / 75$ & 0.6 & 312 & 1.8 \\
\hline LS7B, $3 \mathrm{p} / \mathrm{m}$ & $1: 2.2$ & 46 & 34.1 & 31.3 & $54 / 75$ & 0.46 & 260 & 1.9 \\
\hline $\mathrm{LS} 7 \mathrm{~B}, 4 \mathrm{p} / \mathrm{m}$ & $1: 2.8$ & 36 & 57 & $-1-$ & $60 /-$ & 0.78 & 216 & 2.1 \\
\hline $\mathrm{LS} 7 \mathrm{~B}, 5 \mathrm{p} / \mathrm{m}$ & $1: 4.1^{*}$ & $25^{*}$ & 43.2 & $-1-$ & $58 /-$ & 0.51 & 240 & 2 \\
\hline $\mathrm{LS} 7 \mathrm{~B}, 6 \mathrm{p} / \mathrm{m}$ & - & $-1-$ & $-1-$ & $-1-$ & - & - & 232 & - \\
\hline $\mathrm{LS} 7 \mathrm{~B}, 7 \mathrm{p} / \mathrm{m}$ & - & $-1-$ & $-1-$ & $-1-$ & $-1-$ & - & - & - \\
\hline AVERAGE & $\begin{array}{c}1: 2.5 \\
\text { except* }\end{array}$ & $\begin{array}{c}41 \\
\text { except* }\end{array}$ & 47.6 & 31.9 & $56 / 75$ & 0.59 & 252 & 2 \\
\hline
\end{tabular}

Table 3.- Measurements of quadruped trackway LS7B from Las Sereas 7 (Burgos, Spain). Abbreviations as in tables 1 and 2.

\section{Trackway $L S 7 B$}

LS7B is a quadruped trackway with 12 tracks, oriented north-south (Fig. 2). Morphological characteristics are very similar to those described in LS7A trackway which crosses LS7B (Figs. 2, 3). The manus prints LS7B, 5m and LS7B,6m appear under LS7A,6p and LS7A,7p pes prints, respectively, therefore trackway LS7A was marked after LS7B.
The trackmaker of LS7B had a slightly higher than LS7A (pes print length $63 \mathrm{~cm}$, width $43 \mathrm{~cm}$ ) (Table 3). The pesprint shapes, subrectangular, and the size and position of the four claw marks are similar to the trackway LS7A described above. The manus prints of LS7B are kidney-shaped or semicircular, with digit impressions on LS7B,2m. Heteropody value between pes prints and manus prints is low, 1:2.5. The glenoacetabular distance is $219 \mathrm{~cm}$. Pes prints are deeper 

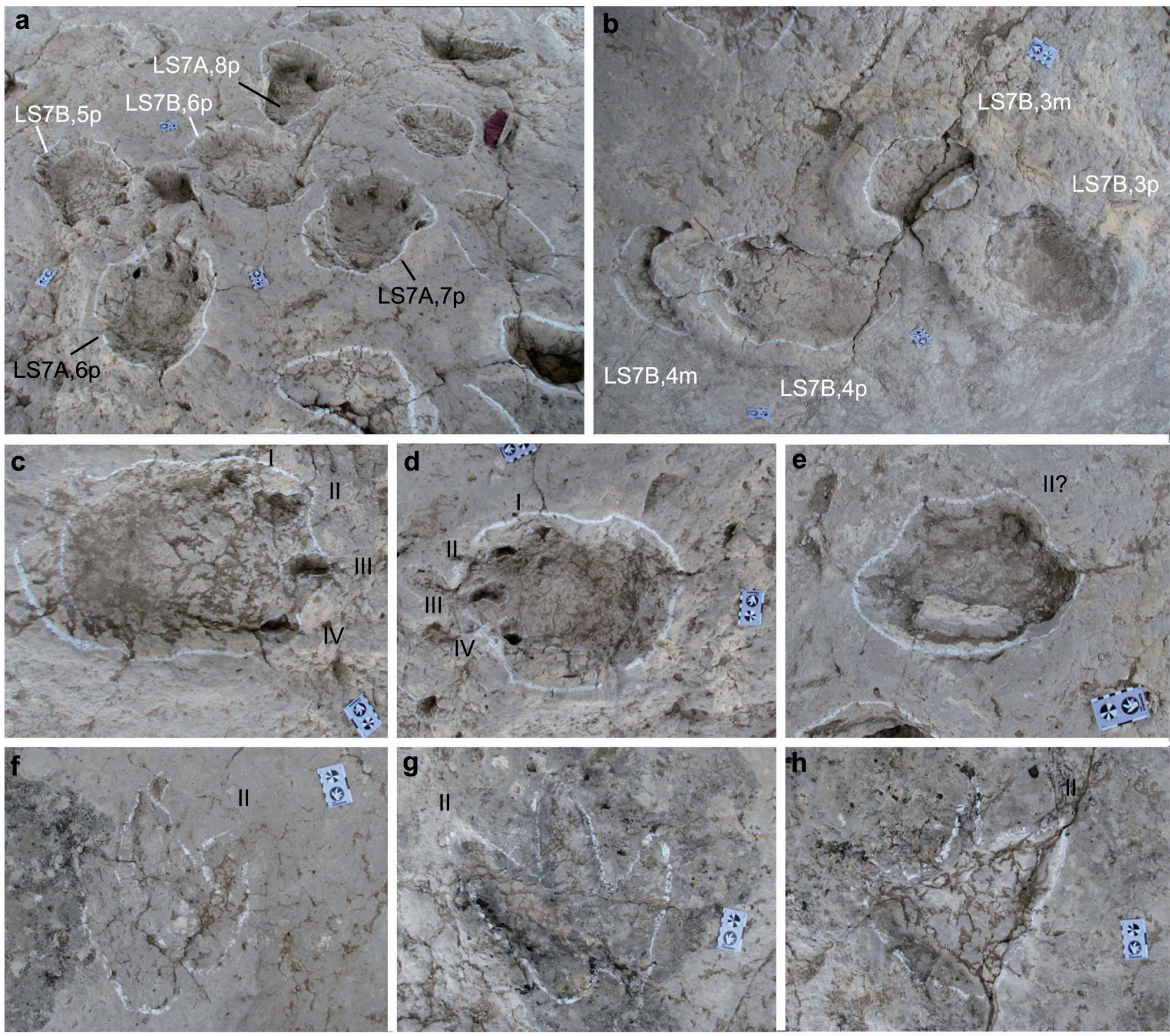

Fig. 3.- a) Picture of a part of the sauropod trackways LS7A and LS7B. b) Picture of a part of the sauropod trackway LS7B. c) Picture of sauropod track LS7B,5p. d) Picture of sauropod track LS7A, 6p. e) Picture of sauropod track LS7A,8m. f) Picture of theropod track LS7D,1. g) Picture of theropod track LS7D, 4. h) Picture of theropod track LS7D,5. Scale bar $=8 \mathrm{~cm}$.

(15 to $20 \mathrm{~cm}$ ) than the manus prints in which the depth is very variable (Fig. 3, 4).

The trackway has intermediate gauge (PTR value: 47.6). The distances between the right and left pes prints are clearly shorter than between left and right pes prints (Table 3, Figs. 2, 3). The rotation values of left and right pes prints differ significantly. In addition the right footprints are deeper than the left.

\section{Trackway LS7C}

LS7C is a quadruped trackway which manifests six tracks, with some intermediate footprints missing. They show southwest-northeast progress (Fig. 2). The pes print length and width averages are $54 \mathrm{~cm}$ and $38 \mathrm{~cm}$. Pes prints are subrectangular, with 4 claw marks with similar shape and position to LS7A and LS7B trackways. Manus prints are kidney-shaped without claw marks.

\section{Discussion}

\subsection{Ichnotaxonomy}

The footprints of biped trackways LS7D and LS7E are better preserved than LS7F. They are mesaxonic and tridactyl footprints, whose digit impressions are elongated and individualized, with some pad impressions in each digit, and with pointed distal ends. The heel impressions are bilobed, formed by the proximal pads of digits II and IV, with IV more backward than II. The footprints are longer than wide 

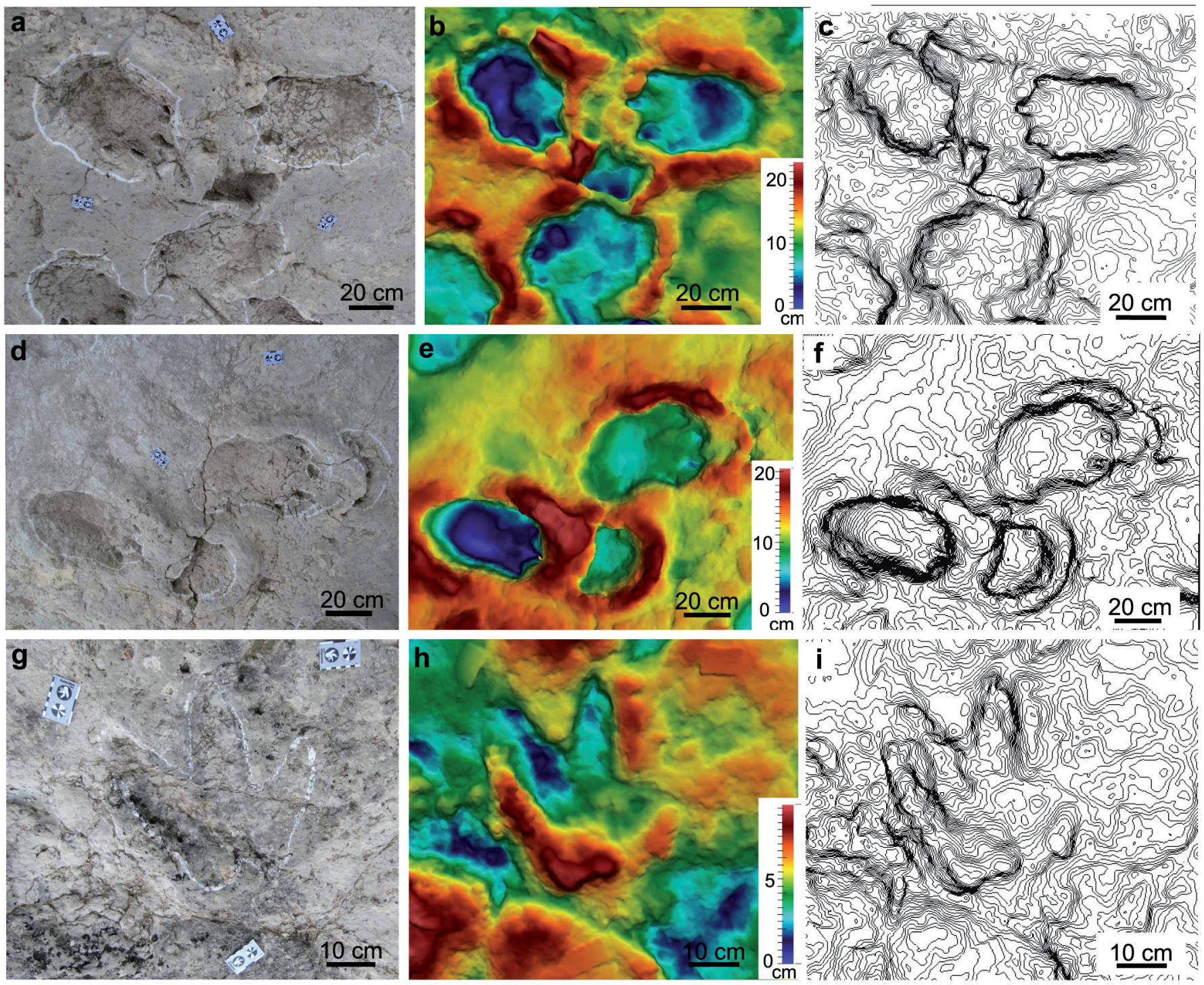

Fig. 4.- a) Picture, b) false-color depth map of the photogrammetric model and c) contour lines map with $0.5 \mathrm{~cm}$ of equidistance of a part of the sauropod trackways LS7A and LS7B. d) Picture, e) false-color depth map of the photogrammetric model and f) contour lines map with $0.5 \mathrm{~cm}$ of equidistance of a part of the sauropod trackway LS7B. g) Picture, h) false-color depth map of the photogrammetric model and i) contour lines map with $0.25 \mathrm{~cm}$ of equidistance of theropod track LS7D,4.

with oval enclosure. These features are common to the proposed definition of theropod footprints (Romero Molina et al., 2003). In addition, the LS7D trackway is very narrow (iTW/FW 0.3; Table 1), typical of theropod trackways according to Pérez-Lorente (2001). However, the footprints are not sufficiently well preserved to assign them to a known ichnotaxon. Therefore, we classified LS7D and LS7E as indeterminate theropod footprints.

The other biped trackway, LS7F, is characterized as tridactyl, mesaxonic, with broad heel impression and short digit impressions. We consider them to be undertracks, and these features could be the result of extramorphological or taphonomical processes. Consequently, we classified these footprints as indeterminate tridactyl dinosaur footprints.

The three quadruped trackways are very similar to each other. The pes prints are longer than wide, with subrectan- gular shape and four claw marks. Claw mark I is smaller and more backwardly than the others. Claw marks I and II are forwardly oriented and III and IV are slightly rotated laterally. The manus prints are not well-preserved. They are roughly symmetrical, wider than long, and have oval shape. In the best examples, they show three to four forwardly digit impressions (Fig. 3c, d). The trackways are narrow-gauge according to the WAP/PL $=0.67<1$ value (Marty, 2008), or intermediate-gauge considering the $\mathrm{PTR}=43.9$ and $47.6<$ $50 \%$ value (Romano et al. 2007), and have low heteropody $(1: 2.5)$.

The Las Sereas 7 quadruped trackways are different from thyreophoran trackways. In stegosaurian ichnotaxa such as Stegopodus Lockley and Hunt, 1998 and Deltapodus Whyte and Romano, 2001, pes prints are mesaxonic, with a triangular contour and three digit impressions forward-oriented (sensu 
Lockley and Hunt, 1998; Whyte and Romano, 2001). In Deltapodus, the manus prints are broadly crescent-shaped with an occasional development of the pollex impression (Whyte and Romano, 2001), and subtriangular in shape with the apex forming the posterior heel impression in Stegopodus (Lockley and Hunt, 1998). In ankylosaurian ichnotaxa, as Metatetrapous Nopcsa, 1923 and Tetrapodosaurus Sternberg, 1932, pes prints are tetradactyl with forward-oriented digit impressions and a subtriangular contour shape (e.g., McCrea et al., 2001; Hornung and Reich, 2014). Manus prints have four (in Metatetrapous) or five (in Tetrapodosaurus) well-developed triangular-shaped digit impressions, three forward-oriented and two backward (sensu McCrea et al., 2001; Hornung and Reich, 2014). Nevertheless, the Las Sereas 7 pes prints are tetradactyl, with a subrectangular contour and with digit I and II impressions forwardly oriented and III and IV impressions laterally curved. The well-preserved manus prints are elliptical and have 3-4 digits, with poorly developed impressions that are forwardly directed.

We relate the quadruped tracks studied in this paper to sauropod tracks: pes prints with four claw impressions, two of them laterally curved, and manus prints with forwardly-oriented digit impressions that are not well-developed (Wright, 2005). In the following lines, we compare these quadruped tracks with the main valid sauropod ichnotaxa (sensu Lockley et al., 2004; Marty et al., 2010).

The Las Sereas 7 tracks differ from Breviparopus taghbaloutensis Dutuit and Ouazzou, 1980 (Upper Jurassic, Morocco) whose features are trackway gauge $(\mathrm{PTR}=51,48)$, high heteropody (1:3,5 - 5), subelliptical-shape pes prints and kidney-shaped manus prints whose claw marks are all laterally oriented (Fig. 5e). The Las Sereas 7 tracks are narrow-gauge, have a heteropody value of 1:3.6, and have a subrectangular pes print with two digits forwardly oriented and other two laterally, (Dutuit and Ouazzou, 1980; Nouri, 2007; Wright , 2005; Marty et al., 2010).

Parabrontopodus mcintoshi Lockley, Farlow, and Meyer, 1994 (Upper Jurassic, USA) is characterized by narrowgauge, elliptical-shape pes print impressions with wellpreserved claw and digit marks laterally oriented and high heteropody (1:4-1:5), (Fig.5f) (Lockley et al., 1994a; Marty et al., 2010). Las Sereas 7 tracks have intermediate-gauge, subrectangular-shape pes print with two digits forwardly oriented and other two laterally, and low heteropody $(1: 2.5)$.

Brontopodus birdii Farlow, Pittman, and Hawthorne, 1989 (Lower Cretaceous, USA) differs from the Las Sereas 7 tracks mainly in the pes print shape (subtriangular in Brontopodus and subrectangular in Las Sereas 7), claw and digit impressions (laterally curved in Brontopodus, and forward and laterally curved in Las Sereas 7), and in the heteropody (high in Brontopodus and low in Las Sereas 7) (Farlow et al., 1989, fig. 5).

Polyonyx gomesi Santos, Moratalla, and Royo-Torres, 2009 (Middle Jurassic, Portugal) is mainly characterized

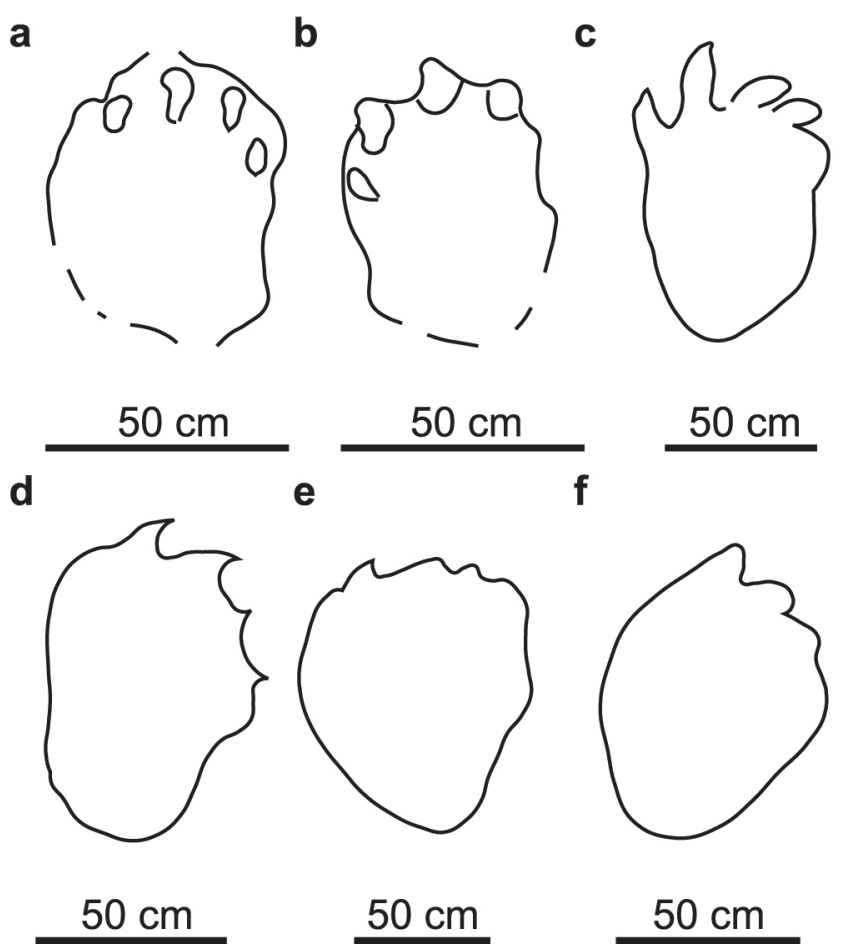

Fig. 5.- Outline drawing of footprints a) LS7A,6p, b) LS7B,5p, c) Polyonyx gomesi (redrawn from Santos et al., 2009), d) Brontopodus birdii (redrawn from Farlow et al., 1989), e) Breviparopus taghbaloutensis (redrawn from Ishigaki and Matsumoto, 2009) and f) Parabrontopodus mcintoshi (redrawn from Lockley et al., 1994a). All are right tracks except a) that is left.

by wide-gauge trackways, pes print with claws I-II with forward orientation and III-IV laterally oriented, asymmetric manus prints with well-developed pollex marks and low heteropody (Santos et al., 2009, fig. 5). Polyonyx differs mainly from Las Sereas 7 tracks in the trackway gauge (wide in Polyonyx and intermediate in Las Sereas 7), in the size and the position of pes digit I impressions (similar size and position in Polyonyx and smaller than digits II and III, and more backward than the other digit impressions in Las Sereas 7), and in the handprint (with pollex mark in Polyonyx and without it in Las Sereas). Despite the above differences, the Burgos tracks share characters with those described for Polyonyx. The trackway gauge can change along the same trackway as the result of changes of direction or variations in the consistency of the substrate (Castanera et al., 2012). Manus print shape is very variable in the Burgos trackways, from oval to kidney shape, due to the pes prints overlapping the manus prints, due to the the lack of preservation of the manus morphology due to the substrate or due to a more digitigrade impression of the manus (Marty et al., 2010). In conclusion, we classified the Las Sereas 7 sauropod tracks as aff. Polyonyx.

The Las Sereas 7 trackways differ from other sauropod tracks found at the Tithonian-Berriasian interval elsewhere in the Iberian Peninsula. In Portugal, some trackways have 
been described in the Lourinhã Formation and the Espichel section of Tithonian age (Lockley et al., 1994c; Santos, 2003; Mateus and Milàn, 2010). In both cases, well-preserved footprints are subtriangular in shape and have laterally curved digit impressions. Castanera et al. (2010a; 2011) described two tracksites in the Villar del Arzobispo Formation (Maestrazgo Basin, Spain) of the Tithonian-Berriasian transition. In Castanera et al. (2010a), the casts of sauropod tracks are composed by triangular footprints with five digit marks (I, II and III laterally oriented) and handprints with pollex impressions. On the other hand, Castanera et al. (2011) analyzed some parallel trackways of small sauropod tracks with oval to subtriangular in shape footprints with five digit marks and lateral orientation, and with kidney-shaped handprints. Platt and Meyer (1991) and Torcida Fernández-Baldor et al. (2001) described some poorly preserved sauropod tracks at the La Pedraja tracksite in the Rupelo Formation (Cameros Basin, Spain) of Tithonian-Berriasian age. According to Torcida Fernández-Baldor et al. (2012), this tracksite is part of the Las Sereas site, but the tracks are different than in the tracksite 7. In Spain, several trackways have been found in the Oncala Group of Berriasian in age (e.g., Casanovas et al. 1992; 1995a; 1995b. 1995c; Meijide et al., 2001; 2004; Pascual-Arribas et al., 2008; PascualArribas and Hernández-Medrano, 2010; Castanera et al., 2012). None of them have subrectangular footprints or digits I and II impression forwardly directed.

This study suggests that the sauropod tracks of Las Sereas 7 classified as aff. Polyonyx are different from all the sauropod tracks found in the Tithonian, at the Tithonian-Berriasian transition, and in the Berriasian of the Iberian Peninsula, but are similar to Polyonyx gomesi found in the Middle Jurassic of Portugal. Santos et al. (2009) suggested that the Polyonyx trackmaker could be a turiasaurid. However, the small size of the digit I claw and the orientation of digits I and II in the Las Sereas 7 sauropod tracks are not described in any known sauropod taxa (sensu Wilson and Sereno, 1998; Wilson, 2002; Upchurch et al., 2004).

\subsection{Palaeoecology}

Las Sereas 7 and La Pedraja (both part of Las Sereas site) are unique tracksites formed in a lacustrine/palustrine environment in the Tithonian-Berriasian interval of the Iberian Peninsula. In Portugal, some tracksites have been described in Tithonian distal alluvial fan deposits with some coastal intercalations (Mateus and Milàn, 2010) and in shallow marine environments (Lockley et al., 1994b; Meyer et al, 1994; Santos, 2003). In the Tithonian-Berriasian transition, several tracksites have been recorded in the Iberian Range (Spain). They formed in transitional, shallow platform to non-marine settings (e.g., Pérez-Lorente et al., 1997; Pérez-Lorente and Herrero-Gascón, 2007; Santisteban et al., 2009; Cobos et al., 2010; Castanera et al., 2011). Berriasian tracksites have been found in fluvial-deltaic deposits with tidal influence environ- ments (Quijada et al., in press) in the Cameros Basin (e.g. Pascual-Arribas et al., 2008; Castanera et al., 2012).

Marginal areas of shallow carbonate-precipitating lacustrine or palustrine environments have been proposed as propitious places for the formation of ichnological sites (Scrivner and Bottjer, 1986). In these shallow lakes, slight changes in water level associated with seasonal oscillations resulted in exposure or flooding of wide areas. During the dry season the lake water would fall to lower levels, exposing wide plains of carbonate mud affected by typical palustrine weathering (Platt, 1989; Alonso-Zarza, 2003; Huerta and Armenteros, 2005). Substrate conditions allowed the impression and preservation of tracks on these lake margins. At Las Sereas, a high ichnodiversity has been described (Torcida Fernández-Baldor et al., 2012). The trackmakers would travel through a muddy plain that, in different places and times, would have different mud consistency conditions. This has been observed in a variety of track shapes within a single trackway and in the track depth. At Las Sereas 7, quadruped trackways are deeper than biped trackways (Fig. 4).

The differences among the ichnofauna of Las Sereas 7 and others tracksites found with similar age in the Iberian Peninsula could thus result from temporal and environmental factors. Las Sereas 7 tracksite includes theropod and intermediate-gauge sauropod trackways. Hunt and Lucas (2006) stated that in Cretaceous outcrops large ornithopod footprints and wide-gauge sauropod trackways are abundant. In contrast, in the Jurassic narrow-gauge sauropod trackways are common and the large ornithopod footprints are scarce. The end of the Jurassic (Kimmeridgian-Tithonian) is considered as the transition from narrow-gauge to wide-gauge sauropods (Lockley et al., 1994c; Wilson and Carrano, 1999). On the other hand, Romano et al. (2007) affirmed that the temporal division of sauropod gauges is not clear. For example, Moratalla (2009) concluded that in the Cameros Basin narrow-gauge trackways are dominant for the Tithonian-Berriasian interval, wide-gauge trackways occur in the Berriasian and narrowgauge trackways are still present and dominate even during the Aptian. The absence of ornithopod footprints at Las Sereas 7 could conform to the Jurassic ichnofaunal record (sensu Hunt and Lucas, 2006). However, as wide-gauge sauropod trackways are more common in the Early Cretaceous (Lockley et al., 1994c; Wilson and Carrano, 1999), this tracksite in the Tithonian-Berriasian interval may display a mixture of Jurassic and Cretaceous ichnotaxa. On the other hand, as suggested above, Las Sereas 7 and La Pedraja (Torcida Fernández-Baldor et al., 2001) are, in the Iberian Peninsula, the unique tracksites of Tithonian-Berriasian lacustrine environments. In addition, the sauropod tracks of Las Sereas differ from others found at the same age and in the same region. This suggests that there could be a relationship between the diversity of Iberian Tithonian-Berriasian interval sauropod tracks and their presence in different ecosystems.

The sum of the Las Sereas site data (Torcida FernándezBaldor et al., 2001; 2012; this study) suggest that its ichno- 
diversity is composed of sauropod, thyreophoran, theropod, and probably ornithopod tracks. This ichnodiversity is consistent with other outcrops in coeval lithostratigraphic units, such as the Vega, Tereñes and Lastres Formations (GarcíaRamos et al. 2007; Lockley et al., 2008); the Villar del Arzobispo Formation (Pérez-Lorente and Herrero-Gascón, 2009; Cobos et al., 2010; Castanera et al. 2010a; 2011; HerreroGascón and Pérez-Lorente, 2012); and the Oncala Group in Spain (Castanera et al., 2012; Pascual et al., 2012); the Iouaridène Formation in Morocco (Boutakiout et al., 2009; Belvedere et al., 2010); the Lourinhã Formation in Portugal (Mateus and Milàn, 2008); and the Morrison Formation in the United States of America (Lockley and Hunt, 1998; Milàn and Chiappe, 2009).

The high diversity of sauropod tracks in this interval suggests a high diversity of sauropod taxa in the Iberian Peninsula. Up to day, six sauropod taxa have been described associated with coastal environments such as tidal flat, fluvial-deltaic plains, and river-floodplain (Lapparent and Zbyszewski, 1957; Bonaparte and Mateus, 1999; Casanovas et al., 2001; Antunes and Mateus, 2003; Royo Torres et al., 2006; Barco, 2009) but none associated with lacustrine environments. Sauropod tracks at Las Sereas 7 differ from others found in the Tithonian-Berriasian interval in Iberia in the shape and in the environment where were produced. Therefore, it is possible that the occurrence of different sauropod taxa in various ichnological outcrops and bone-beds could be related to the different habitats or ecosystems and sedimentary environments in which the dinosaurs lived.

\subsection{Behaviour}

The biped trackways LS7D and LS7E and some isolated footprints have the same orientation in the direction of progression (W-E). The sauropod trackway LS7B and the biped trackway LS7F have similar orientation as well (S-N). On the other hand, the sauropod trackway LS7A heads NE-SW and LS7C is going SE-NW. Biped trackmakers passed before the quadrupeds because in the area where there are more sauropod tracks, bipeds (e.g., trackway LS7D) disappear. With respect to sauropod trackways, the trackmakers likely passed in the following sequence: first LS7B, then LS7A that overlap in at least two footprints of the latest trackway, and finally LS7C that removed some tracks of LS7A.

Sauropod trackways at Las Sereas 7 show similar morphologic features, as described above, but the size of LS7C is somewhat smaller. We suggest that these trackways were made by individuals of the same taxon, and that the different size reflects differences in trackmaker age and/or sex.

From all of these data, it is inferred that there is no evidence of herding behavior or interaction among trackmakers of the same or different taxa.

At tracksite LS7B, differences in length rotation, depth and stride length between right and left steps have been described. These features have been interpreted in the litera- ture as limping gaits or laterality (e.g., Dantas et al., 1994; Pérez-Lorente, 2003). In this case, although trackway LS7B is short, a turning has been identified (see above). The part where the trackway turns shows clear differences in the rotation between left and right tracks like in the LS7B (Fig. 2b). In short trackways, it is difficult to know whether the studied part is straight, or corresponds to a turning trackway of variable amplitude. This is important because changes in direction produce different values in the step length, the rotation of manus and pes for quadrupeds, or trackway gauge (Casanovas et al. 1997; Calvo and Mazzetta 2004; González Riga and Calvo 2009; Ishigaky and Matsumoto, 2009; Castanera et al., 2012) that could be misinterpreted (e.g., limping gaits, different trackmakers). For example, Ishigaki and Matsumoto (2009) studied a long sauropod trackway with some variable values related to changes in direction. This paper present new data from photogrammetric images that allowing turning trackways to be characterized. With depth analysis models, it is possible to quantify whether there are depth differences between right or left steps, which can be used to identify which feet exerted more pressure on the substrate during the turning. In the shorth trackway LS7B, in which the turning is continuously to the right, the right footprints are deeper than the left. The differences of depth between right and left tracks in the same trackway could help to identify the turning in short trackways in which the values of the step length, the rotation of manus and pes for quadrupeds, or trackway gauge could be misinterpreted them as limping gait or used them with ichnotaxonomic/taxonomic sense.

\section{Conclusions}

The Las Sereas 7 tracksite (Burgos) contains biped and quadruped tracks. Biped trackways are not well-preserved and they have been classified as indeterminate theropod footprints (LS7D and LS7E) and indeterminate tridactyl dinosaur footprints (LS7F). The three quadruped trackways are intermediate-gauge and have low heteropody. The pes prints are rectangular and characterized by having four claw marks. Digit I claw mark is the smallest and is more backward than the other claw impressions, claws I-II has forward orientation and III-IV is laterally oriented. These features differ from other known sauropod tracks such as Brontopodus, Parabrontopodus, Breviparopus and Polyonyx. The most similar ichnotaxon is Polyonyx from the Middle Jurassic of Portugal. However, since the Las Sereas 7 trackways lack well-preserved manus prints, we classify them as aff. Polyonyx.

The ichnodiversity of the Las Sereas site is similar to others from the same age composed of sauropod, thyreophoran, theropod and probably ornithopod tracks. The Las Sereas 7 and the La Pedraja tracksites are unique Iberian records from a Tithonian-Berriasian carbonate-precipitating lacustrine/ palustrine environment. Sauropod tracks at Las Sereas 7 differ from others found in the Tithonian-Berriasian interval in 
Iberia, probably due to ecological preferences of the trackmakers.

In this interval, the high diversity of sauropod tracks in the Iberian Peninsula could correspond to a varied sauropod fauna adapted to different ecosystems and ecological niches.

The trackmakers of the sauropod trackways would pertain to the same taxon as they passed in different directions and moments, without showing evidence of gregarious behavior. In two of the trackways, changes in travel direction due to variations in the step length values and in the rotation between left and right steps can be inferred. Photogrammetric models reveal depth variations between left and right footprints, interpreted as resulting from changes in direction. This observation may help to identify this behavior in short trackways that could be misinterpreted as limping or some other unusual gait.

\section{Acknowledgements}

The excavations at Las Sereas 7 received financial support from the Fundación para el Estudio de los Dinosaurios en Castilla y León, in the 2010 and 2011 campaigns. Research of I.D.-M. is supported by the group IT834-13 of the Basque Government and the project CGL2013-47521-P of the Spanish Ministerio de Economía y Competitividad (MINECO), and a Postdoctoral grant from the Ministerio de Ciencia, Tecnología e Innovación Productiva Consejo Nacional de Investigaciones Científicas y Técnicas from Argentina. Red Eléctrica Española (REE) funded a consolidation, protection, and enhancement project of the tracksite in 2011. Thanks to all the people who participated in successive field campaigns and to the municipality of Quintanilla de las Viñas and the Asociación Tierra de Lara for the interest and help in some protection and excavation work. We also thank Keith James for his comments on an early version of the manuscript. The manuscript has greatly benefited from reviews by Dr. Vanda Faria dos Santos and Matteo Belvedere.

\section{References}

Alexander, R.M. (1976): Estimates of speeds of dinosaurs. Nature 261, 129-130. doi: 10.1038/261129a0

Alonso-Zarza, A.M. (2003): Palaeoenvironmental significance of palustrine carbonates and calcretes in the geological record. Earth-Science Reviews 60, 261-298. doi: 10.1016/S0012-8252(02)00106-X

Alonso-Zarza, A.M., Calvo, J.P., García del Cura, M.A. (1992): Palustrine sedimentation and associated features -grainification and pseudo-microkarst- in the Middle Miocene (Intermediate Unit) of the Madrid Basin, Spain. Sedimentary Geology 76, 43-61.

Antunes, M.T., Mateus, O. (2003): Dinosaurs of Portugal. Comptes Rendus Palevol 2, 77-95. doi:10.1016/S1631-0683(03)00003-4

Barco, J.L. (2009): Sistemática e implicaciones filogenéticas y paleobiogeográficas del saurópodo Galvesaurus herreroi (Formación Villar del Arzobispo, Galve, España). Unpublished Doctoral Thesis, Universidad de Zaragoza, Zaragoza, 389 p.

Belvedere, M., Mietto, P., Ishigaki, S. (2010): A Late Jurassic diverse ichnocoenosis from the siliciclastic Iouaridène Formation (Central
High Atlas, Morocco). Geological Quarterly 54, 367-380.

Beuther, A. (1966): Geologische Untersuchungen in Wealden und Utrillas-Schichten im Westteil der Sierra de los Cameros (Nordwestliche Iberische Ketten). Der Jura und Wealden in Nordost-Spanien. Hannover. 44, 103-121.

Bonaparte, J.F., Mateus, O. (1999): A new diplodocid, Dinheirosaurus lourinhanensis gen. et sp. nov., from the Late Jurassic beds of Portugal. Revista del Museo Argentino de Ciencias Naturales 5, 13-29.

Boutakiout, M., Hadri, M., Nouri, J., Díaz-Martínez, I., Pérez-Lorente, F. (2009): Rastrilladas de icnitas terópodas gigantes del Jurásico Superior (Sinclinal de Iouridène, Marruecos). Revista Española de Paleontología 24, 31-46.

Calvo, J., Mazzetta, G.V. (2004): Nuevos hallazgos de huellas de dinosaurios en la Formación Candeleros (Albiano-Cenomaniano), Picún Leufú, Neuquén, Argentina. Ameghiniana 41, 545-554.

Casanovas Cladellas, M.L., Fernández Ortega, A., Pérez-Lorente, F., Santafé Llopis, J.V. (1989): Huellas de dinosaurio de La Rioja. Yacimientos de Valdecevillo, La Senoba y de la Virgen del Campo. Instituto de Estudios Riojanos (IER), Logroño. Ciencias de la Tierra $12,190 \mathrm{p}$.

Casanovas M.L., Ezquerra, R., Fernández, A., Pérez-Lorente, F., Santafé, J.V., Torcida, F. (1992): Un grupo de saurópodos en el yacimiento de Soto 2. La Rioja (España). Zubia 10, 45-52.

Casanovas, J.L., Fernández, A., Pérez-Lorente, F., Santafé, J.V. (1995a): Un terópodo carnosaurio en el camino a Treguajantes (La Rioja, España). Ciencias de la Tierra 18, 13-14.

Casanovas, J.L., Fernández, A., Pérez-Lorente, F., Santafé, J.V. (1995b): Icnitas terópodas y saurópodas en La Cela. Muro en Cameros (La Rioja, España). Ciencias de la Tierra 18, 17-25.

Casanovas, J.L., Ezquerra, R., Fernández, A., Pérez-Lorente, F., Santafé, J.V., Torcida, F. (1995c): Huellas de dinosaurio en el yacimiento de Soto 3 (La Rioja, España). Ciencias de la Tierra 18, 27-28.

Casanovas, M., Fernández, A., Pérez-Lorente, F., Santafé, J.V. (1997): Sauropod trackways from site El Sobaquillo (Munilla, La Rioja, Spain) indicate amble walking. Ichnos 5, 101-107.

Casanovas, M.L., Santafé, J.V., Sanz, J. (2001): Losillasaurus giganteus, un nuevo saurópodo del tránsito Jurásico-Cretácico de la cuenca de "Los Serranos" (Valencia, España). Paleontologia i Evolució 32$33,99-122$.

Castanera, D., Barco, J.L., Canudo, J.I., Pascual, P. (2010a): Aproximación a la diversidad de morfotipos de icnitas de saurópodo en la aloformación Huérteles (Berriasiense) en Soria (España). In: M. Moreno-Azanza, I. Díaz-Martínez, J.M. Gasca, M. Melero-Rubio, R. Rabal-Garcés, V. Sauqué, V. (coords.), Actas VIII Encuentro de Jóvenes Investigadores en Paleontología. Cidaris 30, 91-97.

Castanera, D., Canudo, J.I., Díaz-Martínez, I., Herrero Gascón, J., PérezLorente, F. (2010b): Grandes contramoldes de icnitas de saurópodos en el Tithónico-Berriasiense de la Formación Villar del Arzobispo en Galve (Teruel). In: J.I. Ruiz-Omeñaca, L. Piñuela, J.C. García-Ramos (eds.), Comunicaciones V Congreso del Jurásico de España. Museo del Jurásico de Asturias (MUJA), Colunga, p. 178.

Castanera, D., Barco, J.L., Díaz-Martínez, I., Pérez-Lorente, F., Canudo, J.I. (2011): New evidence of a herd of titanosauriform sauropods from the Lower Berriasian of the Iberian Range (Spain). Palaeogeography, Palaeoclimatology, Palaeoecology 310, 227-237. doi:10.1016/j.palaeo.2011.07.015

Castanera, D., Pascual, C., Canudo, J.I., Hernández, N., Barco, J. (2012): Ethological variations in gauge in sauropod trackways from the Berriasian of Spain. Lethaia 45, 476-489. doi:10.1111/j.15023931.2012.00304.x

Clemente, P. (2010): Review of the Upper Jurassic-Lower Cretaceous stratigraphy in Western Cameros basin, Northern Spain. Revista de la Sociedad Geológica de España 23, 101-143.

Clemente, P., Pérez-Arlucea, M. (1993): Depositional architecture of 
the Cuerda del Pozo Formation, Lower Cretaceous of the Extensional Cameros Basin, North-Central Spain. Journal of Sedimentary Petrology 63, 437-452.

Cobos, A., Royo-Torres, R., Luque, L., Alcalá, L., Mampel, L. (2010): An Iberian stegosaurs paradise: The Villar del Arzobispo Formation (Tithonian-Berriasian) in Teruel (Spain). Palaeogeography, Palaeoclimatology, Palaeoecology 293, 223-236.

Dantas, P., dos Santos, V.F., Lockley, M.G., Meyer, C.A. (1994): Footprint evidence for limping dinosaurs from the Upper Jurassic of Portugal. Gaia, 10, 43-48.

Dutuit, J.M., Ouazzou, A. (1980): Découverte d'une piste de dinosaure sauropode sur le site d'empreintes de Demnate (Haut Atlas marocain). In: Taquet, P. (ed.), Ecosystèmes continentaux du Mésozoïque. Mémoires de la Société Géologique de France N.S. 59, 95-102.

Falkingham, P. L. (2012): Acquisition of high resolution three-dimensional models using free, open-source, photogrammetric software. Palaeontologia Electronica 15(1), 1T:15p.

Farlow, J.O., Pittman, J.F., Hawthorne, J.M. (1989): Brontopodus birdi, Lower Cretaceous Sauropod footprints from the U.S. Gulf Coastal Plain. In: D. D. Gillette y M. G. Lockley (eds.), Dinosaur Tracks and Traces. Cambridge University Press, 371-393.

García-Ramos, J.C., Piñuela, L., Lires, J. (2007): Atlas del Jurásico de Asturias. Ediciones Nobel, Oviedo, 118 p.

González Riga, B., Calvo, J.O. (2009): A new wide-gauge sauropod track site from the Late Cretaceous of Mendoza, Neuquén Basin, Argentina. Palaeontology 52, 631-40. doi: 10.1111/j.1475-4983.2009.00869.x

Haubold, H. (1971): Ichnia Amphibiorum et Reptiliorum fossilium. In: O. Kuhn (ed.), Handbuch der Paläoherpetologie 18. Gustav Fischer Verlag, Stuttgart, $123 \mathrm{p}$.

Herrero Gascón, J., Pérez-Lorente, F. (2012): El Rompido (Aguilar de Alfambra). Icnitas de dinosaurios en la Formación Villar del Arzobispo (Teruel). Geogaceta 51, 39-42.

Hornung, J. J., Reich, M. (2014): Metatetrapous valdensis Nopcsa, 1923 and the presence of ankylosaur tracks (Dinosauria: Thyreophora) in the Berriasian (Early Cretaceous) of northwestern Germany. Ichnos 21, 1-18. doi: 10.1080/10420940.2013.873720

Huerta, P., Armenteros, I. (2005): Calcrete and palustrine assemblages on a distal alluvial-floodplain: A response to local subsidence (Miocene of the Duero basin, Spain). Sedimentary Geology 177, 253 270. doi:10.1016/j.sedgeo.2005.03.007

Huerta, P., Armenteros, I., Silva, P.G. (2011): Large-scale architecture in non-marine basins: The response to the interplay between accommodation space and sediment supply. Sedimentology 58, 1716-1736. doi: 10.1111/j.1365-3091.2011.01231.x

Hunt, A.P., Lucas, S.G. (2006): Tetrapod ichnofacies of the Cretaceous. New Mexico Museum of Natural History and Science Bulletin 35, 62-67.

Ishigaki, S., Matsumoto, Y. (2009): “Off-tracking” like phenomenon observed in the turning sauropod trackway from the Upper Jurassic of Morocco. Memoir of the Fukui Prefectural Dinosaur Museum 8, $1-10$.

Lapparent, A.F., Zbyszewski, G. (1957): Les Dinosauriens du Portugal. Mémoires des Services Géologiques du Portugal N.S. 2, 1-61.

Leonardi, G. (1987): Glosary and Manual of Tetrapod footprint palaeoichnology. Ministerio das Minas e Energia, Departamento Nacional de Produçao Mineral, Brasilia, 75 p.

Lockley, M.G., Farlow, J.O., Meyer, C.A. (1994a): Brontopodus and Parabrontopodus ichnogen. nov. and the significance of wide- and narrow-gauge sauropod trackways. Gaia 10, 135-145.

Lockley, M.G., Meyer, C.A., Santos, V.F. (1994b): Trackway evidence for a herd of juvenile sauropods from the Late Jurassic of Portugal. Gaia 10, 27-35.

Lockley, M.G., Meyer, C.A., Hunt, A.P., Lucas, S.G. (1994c): The distribution of sauropod tracks and trackmakers. Gaia 10, 233-248.
Lockley, M.G., Hunt, A.P. (1998): A probable stegosaur track from the Morrison Formation of Utah. Modern Geology 23, 331-342.

Lockley, M.G., Wright, J.L., Thies, D. (2004): Some observations on the dinosaur tracks at Münchenhagen (Lower Cretaceous), Germany. Ichnos 11, 262-274.

Lockley, M., García-Ramos, J.C., Piñuela, L., Avanzini, M. (2008): A review of vertebrate track assemblages from the Late Jurassic of Asturias, Spain with comparative notes on coeval ichnofaunas from the western USA: implications for faunal diversity in siliciclastic facies assemblages. Oryctos 8, 53-70.

Martín-Closas, C., Alonso Millán, A. (1998): Estratigrafía y bioestratigrafía (Charophyta) del Cretácico inferior en el sector occidental de la Cuenca de Cameros (Cordillera Ibérica). Revista de la Sociedad Geológica de España 11, 253-270.

Marty D. (2008): Sedimentology, taphonomy, and ichnology of Late Jurassic dinosaur tracks from the Jura carbonate platform (Chevenez-Combe Ronde tracksite, NW Switzerland): insights into the tidalflat palaeoenvironment and dinosaur diversity, locomotion, and palaeoecology. Ph.D. Thesis, University of Fribourg. GeoFocus 21, 386 p.

Marty, D., Belvedere, M., Meyer, C. A., Mietto, P., Paratte, G., Lovis, C., Thüring, B. (2010): Comparative analysis of Late Jurassic sauropod trackways from the Jura Mountains (NW Switzerland) and the central High Atlas Mountains (Morocco): implications for sauropod ichnotaxonomy. Historical Biology 22, 109-133. doi: 10.1080/08912960903503345

Mateus, O. \& Milàn, J. (2008): Ichnological evidence for giant ornithopod dinosaurs in the Upper Jurassic Lourinhã Formation, Portugal. Oryctos 8, 47-52.

Mateus, O., Milàn, J. (2010): A diverse Upper Jurassic dinosaur ichnofauna from central-west Portugal. Lethaia 43, 245-257. doi:10.1111/ j.1502-3931.2009.00190.x

McCrea, R., Lockley, M. G., Meyer, C.A. (2001): Global distribution of purported ankylosaur track occurrences. In: K. Carpenter (ed.), The Armored Dinosaurs. Indiana University Press, Bloomington, pp. 413-454.

Meijide Fuentes, F., Fuentes Vidarte, C., Meijide Calvo, M. (2001): Primeras huellas de saurópodo en el Weald de Soria (España), $\mathrm{Pa}$ rabrontopodus distercii, nov. ichnoesp. In: Colectivo ArqueológicoPaleontológico salense (ed.), Actas I Jornadas internacionales sobre Paleontología de Dinosaurios y su Entorno, Salas de los Infantes, Burgos, pp. 407-415.

Meijide Fuentes, F., Fuentes Vidarte, C., Meijide Calvo, M., Meijide Fuentes, M. (2004): Rastro de un dinosaurio Saurópodo en el Weald de Soria (España). Brontopodus oncalensis nov. icnsp. Celtiberia, 98, 501-515.

Meyer, C.A., Lockley, M.G., Robinson, J.W., Santos, V.F. dos (1994): A comparison of well-preserved sauropod tracks from the Late Jurassic of Portugal and the Western United States: evidence and implications. Gaia 10, 57-64.

Milàn, J., Chiappe, L.M. (2009): First American record of the Jurassic ichnospecies Deltapodus brodricki and a review of the fossil record of stegosaurian footprints. Journal of Geology 117, 343-348. doi: $10.1086 / 597363$

Moratalla, J. J. (2009): Sauropod tracks of the Cameros Basin (Spain): Identification, trackway patterns and changes over the Jurassic-Cretaceous. Geobios 42, 797-811. doi: 10.1016/j.geobios.2009.06.00

Nopcsa, F. (1923): Note on British Dinosaurs, Part VI, Acanthopolis. Geological Magazine 60, 193-199.

Nouri, J. (2007): La paléoichnologie des empreintes de pas de dinosauriens, imprimées dans les couches du Jurassique, du Haut-Atlas central du Maroc. Ph.D. Thesis, Université Mohammed V, Rabat, 250 p.

Pascual-Arribas, C., Hernández Medrano, N., Latorre Macarrón, P., Sanz Pérez, E. (2008): Estudio de un rastro de huellas de saurópodo 
del yacimiento de Las Cuestas I (San Cruz de Yanguas, Soria, España). Implicaciones taxonómicas. Studia geologica salmanticensia $44,13-40$

Pascual-Arribas, C., Hernández-Medrano, N. (2010): Nuevos datos sobre el yacimiento icnítico de Las Cuestas I (Santa Cruz de Yanguas, Soria. España). Studia geologica salmanticensia 46, 121-157.

Pascual, C., Canudo, J.I., Hernández, N., Barco, J.L., Castanera, D. (2012): First record of stegosaur dinosaur tracks in the Lower Cretaceous (Berriasian) of Europe (Oncala Group, Soria, Spain). Geodiversitas 34, 297-312. doi: 10.5252/g2012n2a4

Pérez-Lorente, F. (2001): Paleoicnología. Los dinosaurios y sus huellas en La Rioja: apuntes para los cursos y campos de trabajo de verano. Cultural Joven, Logroño, Gobierno de La Rioja, 227 p.

Pérez-Lorente, F. (2003): Icnitas de dinosaurios del Cretácico en España. In: F. Pérez-Lorente (ed.), Dinosaurios y otros reptiles mesozoicos de España, Instituto de Estudios Riojanos (IER), Logroño. Ciencias de la Tierra 26, 49-108.

Pérez-Lorente, F., Herrero Gascón, J. (2007): El movimiento de un dinosaurio deducido de una rastrillada terópoda con estructuras de inmersión en los pies en barro y de arrastre de cola (Formación Villar del Arzobispo. Galve, Teruel, España). Revista Española de Paleontología 22, 157-174.

Pérez-Lorente, F., Herrero-Gascón, J. (2009): New Upper Jurassic and Lower Cretaceous dinosaur footprints casts discovered in Galve (Teruel). In: Universidad Autónoma de Madrid (ed.), Tenth international Symposium on Mesozoic Terrestrial Ecosystems and Biota, Teruel, pp. 251-252.

Pérez-Lorente, F., Cuenca-Bescós, G., Aurell, M., Canudo, J.I., Soria, A.R., Ruiz-Omeñaca, J.I. (1997): Las Cerradicas tracksite (Berriasian, Galve, Spain): Growing evidence for quadrupedal ornithopods. Ichnos 5, 109-120. doi: 10.1080/10420949709386410

Platt, N.H. (1986): Sedimentology and tectonics of the western Cameros Basin. Province of Burgos, Northern Spain. Ph.D. Thesis, University of Oxford, $125 \mathrm{p}$.

Platt, N.H. (1989): Lacustrine carbonates and pedogenesis - Sedimentology and origin of palustrine deposits from the Early Cretaceous Rupelo Formation, W Cameros Basin, N Spain. Sedimentology 36, 665-684

Platt, N.H., Meyer, C. (1991): Dinosaur footprints from the Lower Cretaceous of northern Spain: their sedimentological and palaeoecological context. Palaeogeography, Palaeoclimatology, Palaeoecology 85, 321-333. doi: 10.1016/0031-0182(91)90165-N

Quijada, I. E., Suárez-González, P., Benito, M. I., Mas, R. (in press): Tidal versus continental sandy-muddy flat deposits: evidence from the Oncala Group (Early Cretaceous, N Spain). In: B. Tessier, J.Y. Reynaud (eds.), International Association of Sedimentologists Special Publication 48, in press.

Romano, M., Whyte, M. A., Jackson, S. J. (2007): Trackway ratio: a new look at trackway gauge in the analysis of quadrupedal dinosaur trackways and its implications for icnotaxonomy. Ichnos 14, 257-270. doi:10.1080/10420940601050014

Romero-Molina, M.M., Sarjeant, W.A.S., Pérez-Lorente, F., López, A., Requeta, E. (2003): Orientation and characteristics of theropod trackways from the Las Losas palaeoichnological site (La Rioja, Spain). Ichnos 10, 241-254. doi: 10.1080/10420940390255529

Royo-Torres, R., Cobos, A., Alcalá, L. (2006): A giant European dinosaur and a new sauropod clade. Science 314, 1925-1927. doi: 10.1126/science. 1132885

Santisteban, C., Suñer, M., Vila, B. (2009): El yacimiento de icnitas de dinosaurios de Cañada Paris, Alpuente, Valencia. In: P. Huerta, F. Torcida Fernández-Baldor (eds.), Actas IV Jornadas Internacionales so- bre Paleontología de Dinosaurios y su Entorno, Salas de los Infantes, Burgos, pp. 301-309.

Santos, V.F. 2003. Pistas de dinossáurio no Jurássico-Cretácico de Portugal. Considerações paleobiológicas e paleoecológicas. Unpublished Ph.D. Thesis, Universidad Autónoma de Madrid, Madrid, 365 p.

Santos, V.F., Moratalla, J.F., Royo-Torres, R. (2009): New sauropod trackways from the Middle Jurassic of Portugal. Acta Palaeontologica Polonica 54, 409-422. doi: 10.4202/app.2008.0049

Scrivner, P., Bottjer, D. J. (1986): Neogene avian and mammalian tracks from Death Valley National Monument, California: their context, classification y preservation. Palaeogeography, Palaeoclimatology, Palaeoecology 57, 285-331. doi: 10.1016/0031-0182(86)90017-9

Sternberg, C.M. (1932): Dinosaur tracks from Peace River, British Columbia. Annual Report of the National Museum of Canada 1930, 59-85.

Thulborn, T. (1990): Dinosaur tracks. Chapman and Hall, London, 410 p. Torcida Fernández-Baldor, F. (1996): Registro de dinosaurios en el sureste de la provincia de Burgos. Zubía 14, 89-104.

Torcida, F., Izquierdo, L.A., Montero, D., Pérez, G., Urién, V. (2001): Primera cita de huellas de saurópodos en Burgos (España). In: Colectivo Arqueológico-Paleontológico Salense (ed.), Actas I Jornadas internacionales sobre Paleontología de Dinosaurios y su entorno, Salas de los Infantes, Burgos, pp. 427-434.

Torcida Fernández-Baldor, F., Huerta, P., Montero Huerta, D., Contreras, R., Pérez-Martínez, G., Urién Montero, V. (2006): Un extenso yacimiento de icnitas de dinosaurios del tránsito Jurásico SuperiorCretácico Inferior de Burgos. Resúmenes XXII Jornadas de la Sociedad Española de Paleontología, León, pp. 185-187.

Torcida Fernández-Baldor, F., Contreras Izquierdo, R., Huerta, P., Montero Huerta, D., Pérez Martínez, G., Urién Montero, V. (2008): Un dinosaurio ornitópodo de gran talla en el tránsito Jurásico-Cretácico de Burgos (España). Studia geologica salmanticensia volumen especial 8, 85-94.

Torcida Fernández-Baldor, F., Díaz-Martínez, I., Huerta, P., ContrerasIzquierdo, R., Izquierdo Montero, L.A., Montero Huerta, D., Urién Montero, V. (2012): Estudio previo del yacimiento de icnitas de dinosaurios de Las Sereas (Cuenca de Cameros, Jurásico SuperiorCretácico Inferior). In: P. Huerta Hurtado, F. Torcida Fernández-Baldor, J.I. Canudo Sanagustín (eds.), Actas V Jornadas internacionales sobre Paleontología de Dinosaurios y su entorno, pp. 197-204.

Upchurch, P., Barrett, P. M., Dodson, P. (2004): Sauropoda. In: D.B. Weishampel, P. Dodson \& H. Osmólska (eds.), The Dinosauria, $2^{\text {nd }}$ edition. University of California Press, Berkeley, pp. 259-322.

Whyte, M.A., Romano, M. (2001): Probable stegosaurian dinosaur tracks from the Saltwick Formation (Middle Jurassic) of Yorkshire, England. Proceedings of the Geologists' Association 112, 45-54. doi: 10.1016/S0016-7878(01)80047-X

Wilson, J.A. (2002): Sauropod dinosaur phylogeny: critique and cladistic analysis. Zoological Journal of the Linnean Society 136, 215-275. doi: 10.1046/j.1096-3642.2002.00029.x

Wilson, J.A., Sereno, P.C. (1998): Early evolution and higher-level phylogeny of sauropod dinosaurs. Society of Vertebrate Paleontology Memoir 5, supplement to Journal of Vertebrate Paleontology 18, 1-68. doi: 10.1080/02724634.1998.10011115

Wilson, J.A., Carrano, M.T. (1999): Titanosaurs and the origin of "widegauge" trackways: a biomechanical and systematic perspectives on sauropod locomotion. Paleobiology 25, 252-267.

Wright, J.L. (2005): Steps in understanding sauropod biology: the importance of sauropod tracks. In: K.A. Curry Rogers, J.A. Wilson (eds.), The Sauropods: Evolution and Paleobiology. University of California Press, Berkeley, pp. 252-284. 